\title{
PENGEMBANGAN HANDOUT BERBASIS KONTEKSTUAL PADA PELAJARAN BIOLOGI MATERI BIOTEKNOLOGI UNTUK SISWA KELAS XII SMK NEGERI O2 BATU
}

\author{
Fega Rahmayani ${ }^{1}$, Iin Hindun ${ }^{1}$, Atok Miftachul Hudha ${ }^{1}$ \\ ${ }^{1}$ Pendidikan Biologi FKIP Universtias Muhammadiyah Malang, \\ e-mail : atok_emha@yahoo.com
}

\begin{abstract}
The teaching learning activity in SMK is inappropriate with the purpose of teaching and learning in SMK, which the students are taught to be able to apply the materials in the real life. Teaching material is taken from the biology book of SMA that the content is theoretically, so the explanation on the material is unsuitable and not applicative that makes the student less in ability and skill for application in daily life. From the problem above, this research purpose on developing the contextual basic handout of the biological course in biotechnology material in SMK N 02 Batu.This research is developing research based on research and development by Sugiyono's model that use a few developing steps, those are: (1) Potential and problem, (2) Collecting data, (3) Product design, (4) Validation design, (5) Design revision, (6) Try out the product, (7) Product revision. The data collecting methods is using validation from the expert of handout, material expert and try out to the study club. The technique of analyze data using quantitative and qualitative data. The result of quantitative data is the percentage of handout product value that classify in the handout quality and the result of qualitative data come from comment and advise of validator and try out in SMK.The result quality of the handout found that the developing contextual basic handout reach out the good quality after following the procedure of validation with percentage $80.90 \%$ and try out to the student that use the handout with percentage very good, $97.75 \%$ and get the positive respond from student with percentage $90.82 \%$. From the whole of the contextual basic handout have a good quality and appropriate in use for teaching material of Biology in teaching learning process in SMK N 02 Batu.
\end{abstract}

Keywords: Contextual Basic Handout, Development and Quality of Handout.

Peraturan Pemerintah Nomor 19 Tahun 2005 tentang Standar Nasional Pendidikan pasal 6 ayat (1) menyatakan bahwa "pendidikan di SMK adalah untuk menerapkan ilmu pengetahuan dan teknologi, membentuk kompetensi, kecakapan, dan kemandirian kerja". Ditegaskan pula dalam kurikulum Sekolah Menengah Kejuruan (SMK) tahun 2006 bahwa peran SMK adalah menyiapkan siswa dengan kemampuan dan keterampilan bidang tertentu agar setelah lulus dapat bekerja pada bidang tertentu untuk mengisi lowongan yang ada. Namun demikian data Departemen Pendidikan Nasional Tahun 2009 menyebutkan bahwa lulusan SMK masih menjadi penyumbang pengangguran terbesar. Fakta ini menunjukan adanya ketidak sesuaian sehingga perlu adanya strategi pengembangan di SMK yang memperkuat kemandirian lulusan pada program keahlian untuk siap kerja.

Proses belajar mengajar biologi di SMK dinyatakan oleh Badan Standar Pendidikan Nasional (2006) bahwa tujuan pendidikan menengah kejuruan adalah meningkatkan kecerdasan, pengetahuan, kepribadian, akhlak mulia, keterampilan untuk hidup mandiri dan mengikuti studi lebih lanjut sesuai dengan kejuruannya.

Kelemahan pembelajaran di SMK sebagaimana dijelaskan oleh Mulyana (2013) ditemukan hal-hal yang masih harus diperhatikan, hal-hal tersebut menyangkut: 1) masih banyak sekolah yang kekurangan bahan ajar yang bersifat aplikatif dalam arti tidak hanya memaparkan konsep tetapi beberapa materi memerlukan penerapan sehingga menyulitkan guru dalam 
melaksanakan pembelajaran, 2) kurikulum di SMK yang terlalu teoritis dalam arti hanya berisi wawasan pengetahuan, kurang praktis, kurang kontekstual, sehingga kurang memberikan makna proses dari hasil pembelajaran yang berarti bagi bekal kecakapan hidup (life skill) siswa di masa depan.

Menurut Departemen Pendidikan Nasional (2008) menyatakan bahwa dalam pemilihan dan penentuan bahan ajar yang baik adalah memenuhi salah satu kriteria bahwa bahan ajar harus menarik, dapat membantu siswa untuk mencapai kompetensi. Sehingga bahan ajar dibuat sesuai dengan kebutuhan dan kecocokan dengan KD yang akan diraih oleh peserta didik. Jenis dan bentuk bahan ajar ditetapkan atas dasar analisis kurikulum dan analisis sumber bahan sebelumnya. Dari hal tersebut buku teks khusus SMK belum ada dalam proses pembelajaran, sehingga siswa SMK belum bisa mencapai tujuan dalam pembelajaran. Buku teks bagi siswa SMK seharusnya disesuaikan dengan kurikulum yang ada di SMK yaitu dengan melaraskan materi pembelajaran dengan tujuan dalam kurikulum untuk menjadikan pembelajaran di SMK lebih maksimal.

Dalam kurikulum di SMK khususnya materi bioteknologi bahwa tujuan pembelajaran materi bioteknologi mempunyai Standar Kompetensi sebagai berikut: mengidentifikasi pengembangan bioteknologi dan dampaknya bagi kehidupan, dengan Kompetensi Dasar a) mengidentifikasi ciri dan sifat mikroorganisme dalam proses bioteknologi, b) mengidentifikasi dampak pengembangan bioteknologi, mengidentifikasi peranan bioteknologi bagi pertanian sampai kesehatan manusia (Departemen Pendidikan dan Kebudayaan, 2006), sedangkan dalam penyajian materi bioteknologi yang terdapat dibuku teks SMA Standar Kompetensi sebagai berikut: memahami prinsip-prinsip dasar bioteknologi serta implikasinya pada sains, lingkungan, teknologi, masyarakat (salingtemas) dengan kompetensi dasar a) menjelaskan arti, prinsip dasar, dan jenisjenis bioteknologi dan, b) menjelaskan dan menganalisis peran bioteknologi serta implikasi hasil-hasil bioteknologi pada salingtemas (Permendiknas No. 22 Tahun 2006). Berdasarkan dua sumber kurikulum diatas, maka penyampaian pembelajaran di SMK belum sesuai dengan kompetensi pembelajaran materi bioteknologi di SMK program keahlian pertanian.

Departemen Pendidikan Nasional (2008) menyatakan bahwa tujuan dari membuat bahan ajar adalah menyediakan bahan ajar yang sesuai dengan tuntutan kurikulum dengan mempertimbangkan kebutuhan siswa, yakni bahan ajar yang sesuai dengan karakteristik dan setting atau lingkungan sosial siswa, membantu siswa dalam memperoleh alternatif bahan ajar di samping buku-buku teks yang terkadang sulit diperoleh dan memudahkan guru dalam melaksanakan pembelajaran (Departemen Pendidikan Nasional, 2008). Dilanjutkan oleh Prastowo, A (2012) mengemukakan "bahan ajar yang digunakan untuk melengkapi bahan ajar yang mempunyai kekurangan dalam mencapai tujuan dalam proses pembelajaran yang bisa disesuaikan dengan karakteristik peserta didik, jenis materi pelajaran, kondisi lingkungan dan dapat memotivasi serta meningkatkan belajar siswa pada pelajaran biologi yaitu bahan ajar berupa handout". Handout dikembangkan berdasarkan kondisi siswa yang sesuai dengan tujuan pembelajaran yaitu bisa menerapkan materi secara jelas dalam proses pembelajaran dengan kehidupan sehari-hari.

Menurut Aziz (2010) dalam Amir (2012) penggunaan bahan ajar berupa handout bisa lebih memberdayakan peserta didik dalam menerapkan pembelajaran dengan kurikulum yang ada dalam buku teks. Dalam hal ini handout bisa melengkapi kelemahan buku teks dalam proses pembelajaran. Dalam proses pembelajaran lebih mengedepankan 
idealitas bagi pendidik sehingga benarbenar akan menghasilkan kualitas pembelajaran yang efektif dan efisien yang sesuai dengan kurikulum.

Pembelajaran kontekstual merupakan proses belajar yang membantu guru mengaitkan antara materi yang diajarkan dengan situasi dunia nyata peserta didik dan mendorong peserta didik membuat hubungan antara pengetahuan yang dimilikinya dengan penerapannya dalam kehidupan. Dengan konsep itu, hasil pembelajaran diharapkan lebih bermakna bagi peserta didik. Proses pembelajaran berlangsung alamiah dalam bentuk kegiatan peserta didik bekerja dan mengalami bukan mentransfer pengetahuan dari guru ke peserta didik. Strategi pembelajaran lebih dipentingkan daripada hasil (Elaine, 2007).

Dari hasil studi pendahuluan yang dilakukan peneliti melalui pengamatan langsung dan wawancara pada guru bidang studi biologi dan peserta didik di SMK Negeri 02 Batu bahwa pada kesimpulannya proses belajar biologi guru menggunakan bahan ajar berupa buku teks biologi SMA sebagai acuan belajar dalam proses mengajar, dan didapatkan secara fakta informasi bahwa jumlah buku teks yang digunakan siswa dalam belajar sangat terbatas dan buku teks tersebut diletakkan di perpustakaan sekolah, sehingga sebagaian besar siswa tidak memiliki buku teks biologi selain LKS (Lembar Kegiatan Siswa) sebagai bahan ajar yang siswa miliki. LKS berisi tentang uraian singkat materi dengan tujuan pembelajaran yang sama dengan buku teks, sehingga buku teks SMA yang digunakan siswa belum mendukung kurikulum di SMK, dan siswa dalam menyelesaikan pertanyaan yang ada di LKS dengan cara memindahkan sebagian materi ke dalam pertanyaan tersebut dan ketika siswa tidak bisa menyelesaikan pertanyaan, siswa mengosongkan dan menunggu siswa yang lain bisa mengerjakan, sehingga kegiatan pembelajaran belum bisa mengasah kemampuan berpikir siswa, sehingga diperlukan bahan ajar lain yang bisa melengkapi kelemahan dari kurikulum yang ada di buku teks SMA dan LKS yaitu kurikulum yang disesuaikan dengan pembelajaran di SMK untuk memberikan kesempatan pada siswa membangun pengetahuan yang tidak sekedar sebagai penerima bahan ajaran, tetapi juga bisa mencapai tujuan pembelajaran yaitu bisa menerapkan materi untuk bisa diterapkan.

Alternatif dalam mengatasi kesulitan-kesulitan tersebut dapat diatasi dan disiasati oleh guru biologi dalam pelengkapi kelemahan dari buku teks SMA dengan disusun dan dikembangkannya handout berbasis kontekstual materi bioteknologi yang berkualitas dan sesuai dengan kriteria penyusunan handout yang baik. Handout merupakan salah satu bentuk media cetak yang mudah dikembangkan dan dapat dimanfaatkan dalam pembelajaran untuk memperlancar pelaksanaan belajar mengajar yang disesuaikan kurikulum.

Keunggulan dalam penggunaan handout berbasis kontekstual untuk pengembangan bahan ajar dalam proses pembelajaran dapat dilihat dari beberapa hasil penelitian terdahulu yang juga menggunakan handout berbasis kontesktual oleh Sufatmi Amir (2012) handout mampu melengkapi kelemahan buku teks Kimia dan mempunyai kualitas baik (B), dan penelitian oleh Turnasih (2013) handout digunakan oleh guru sebagai acuan untuk digunakan sebagai sumber belajar bagi peserta didik SMA/MA dan mempunyai kualitas yang baik.

Dengan disusunnya handout berbasis kontekstual untuk pembelajaran materi bioteknologi diharapkan siswa dapat menerapkan pembelajaran dalam kehidupan nyata dan membangun pengetahuannya sendiri. Berdasarkan penelusuran dari beberapa permasalahan yang ada, maka peneliti mencoba menjawab permasalahan di SMK Negeri 02 Batu dengan penelitian yang berjudul "Pengembangan Handout Berbasis 
Kontekstual pada Pelajaran Biologi Materi Bioteknologi untuk Siswa Kelas XII SMK Negeri 02 Batu"

\section{METODE}

Penelitian ini merupakan jenis penelitian pengembangan (Research and Development) merupakan penelitian yang digunakan untuk menghasilkan produk tertentu, dan menguji kualitas produk tersebut. Penelitian pengembangan (Research and Development atau $R \& D$ ) adalah aktifitas riset dasar untuk mendapatkan informasi kebutuhan pengguna (needs assessment), kemudian dilanjutkan kegiatan pengembangan (development) untuk menghasilkan produk sebagai bahan ajar bagi siswa dan menguji kualitas produk tersebut (Sugiyono, 2011).

Model pengembangan yang
digunakan
pembelajaran ini didasarkan pada rancangan pengembangan (Research and Development) menurut model Sugiyono (2011). Langkah-langkah pengembangan meliputi: (1) Potensi dan masalah, (2) Pengumpulan data, (3) Desain produk, (4) Validasi desain, (5) Revisi desain, (6)
Ujicoba produk, (7) Revisi produk. Secara rinci dapat dilihat pada prosedur pengembangan handout pada halaman berikutnya (gambar 1). tahapan dalam pengumpulan data yang dilakukan meliputi : Mengkaji kurikulum, Mempelajari kurikulum yang ada di SMK Negeri 02 Batu sehingga handout bioteknologi berbasis kontektual yang akan dihasilkan tidak menyimpang dari tujuan pengajaran disekolah. Mengidentifikasi materi yang dibutuhkan untuk pembuatan handout, sehingga dapat dipahami oleh peserta didik kelas XII. Mengindentifikasi materi dilakukan melalui beberapa cara yaitu: diskusi dengan guru mata pelajaran biologi dan kepala sekolah, kemudian dilanjutkan dengan observasi yang dilakukan disekolahan khususnya dikelas XII SMK dan wawancara dengan guru mata pelajaran biologi dan siswa SMK kelas XII. Studi Literatur ditujukan untuk menemukan konsep-konsep atau landasanlandasan teoritis yang memperkuat suatu produk pendidikan berbasis (handout bioteknologi kontekstual). 


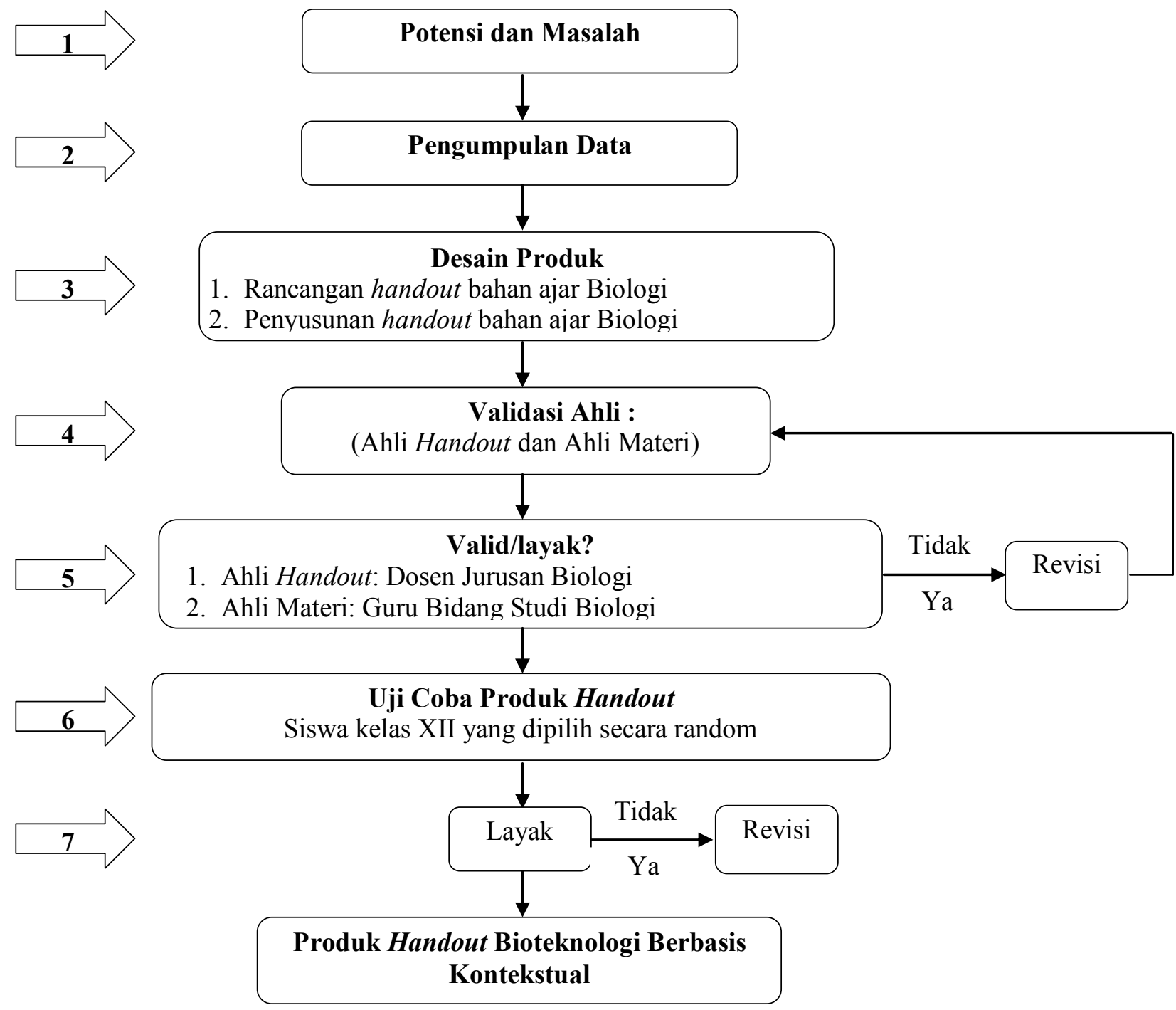

Gambar 1. Model Pengembangan Handout Bioteknologi Berbasis Kontekstual (Dimodifikasi dari model Pengembangan Sugiyono, 2011)

Dalam menyusun rancangan handout biologi berbasis kontekstual bagi siswa kelas XII dalam proses pembelajaran yang dilakukan adalah merancang handout biologi ini dengan mengikuti pedoman penyusunan handout berbasis kontekstual yang baik dan benar dirumuskan melalui tahapan berikut: (1) Halaman depan yang terdiri dari: judul handout, nama penyusun, ilustrasi gambar dan penerbit. (2) Pendahuluan dari uraian singkat tentang tema bioteknologi yang terdiri dari uraian singkat dari tema bioteknologi, standar kompetensi, kompetensi dasar dan tujuan pembelajaran serta petunjuk teknis dalam pembelajaran menggunakan handout. (3) Kegiatan belajar siswa terdapat 3 macam kompetensi dasar.

Validasi desain pada ahli merupakan kegiatan yang dilakukan oleh ahli untuk memeriksa dan mengevaluasi secara sistematis instrumen dan produk yang akan dikembangkan sesuai dengan tujuan. Hal ini dilakukan oleh ahli handout dan ahli materi. Adapun yang divalidasi meliputi (1) Halaman sampul 
(cover), (2) Pendahuluan yang terdiri dari uraian singkat materi isi, tujuan pembelajaran, kegunaan handout, petunjuk teknis untuk siswa, (3) Isi handout yang terdiri dari uraian materi pada kegiatan 1, 2, 3 dan kegiatan kontekstual, (4) Pelengkap terdiri dari uji kompetensi, gambar, rangkuman dan rujukan. Dibawah ini kriteria validator ahli yang memvalidasi produk handout. Validator mengisi angket dalam kriteria ahli handout untuk memberikan penilaian. Ahli handout berbasis kontekstual pada pelajaran biologi materi bioteknologi adalah Dr. Yuni Pantiwati, M.Pd. selaku dosen biologi di jurusan biologi di Universitas Muhammadiyah Malang sebagai ahli handout 1 dan Prof. Dr. A.D. Corebima, M.Pd. selaku dosen biologi di Universitas Negeri Malang sebagai ahli handout 2. Ahli materi pada pengembangan handout berbasis kontekstual pada pelajaran biologi materi bioteknologi adalah Siti Sulichah, S.Pd, M.Pd selaku guru biologi di SMK Negeri 02 Batu.

Setelah dilakukan validasi oeh validatori. Validasi handout dilakukan untuk mengetahui kekurangan dan kelemahan handout biologi, oleh karena itu diperlukan revisi atau perbaikan desain sehingga handout biologi tersebut dinyatakan layak dan bisa digunakan sebagai bahan ajar materi bioteknologi.

Ujicoba handout pada tahap ini dilakukan oleh siswa kelas XII di SMK Negeri 02 Batu setelah divalidasi dan revisi. Tahap ini akan dilakukan uji coba terbatas yaitu diambil secara random 15 siswa kelas sebagai pengguna produk handout. Uji coba produk handout yang telah selesai dikerjakan segera diketahui hasil belajar siswa dengan cepat dan dapat diketahui kelayakan handout yang telah disusun. Tahap uji coba menggunakan handout supaya mengetahui nilai manfaat dalam penguasaan handout dari masing-masing siswa,

Setelah melakukan uji coba produk handout dan mengetahui kekurangan dan kelemahan handout, maka peneliti melakukan perevisian produk dengan tujuan untuk mengetahui nilai manfaat handout yang dikembangkan, sehingga menjadi handout biologi bioteknologi berbasis kontekstual yang sempurna.

Desain uji coba dalam pengembangan handout ini meliputi validasi isi dan uji coba produk handout. Validasi isi dilakukan oleh validator dengan mengisi angket lembar validasi guna memberikan penilaian terhadap handout bioteknologi berbasis kontekstual yang telah disusun. Desain validasi yang digunakan adalah deskriptif yang memungkinkan pengembang memperoleh informasi/data secara kualitatif dan kuantitatif. Tahap validasi ini, produk pengembangan handout bioteknologi berbasis kontekstual kemudian divalidasikan kepada guru ahli handout dan guru SMK Negeri 02 Batu yang telah berkompeten dibidang biologi sebagai ahli materi.

Langkah-langkah yang dilakukan dalam tahap review validator yaitu 1) Mendatangi validator yaitu ahli handout Dr. Yuni Pantiwati, M.Pd dan Prof. Dr. A.D. Corebima, M.Pd dan ahli materi Drs. Siti Sulichah, M.Pd, 2) Menjelaskan model pengembangan yang akan dilakukan, 3) Meminta saran dan komentar mengenahi handout bioteknologi berbasis kontekstual yang dikembangkan melalui angket, setelah dilakukan validasi ahli kemudian dilakukan revisi atau perbaikan handout bioteknologi berbasis kontekstual kemudian diuji cobakan pada siswa, hal ini dilakukan untuk mengetahui apakah handout bioteknologi berbasis kontekstual tersebut layak/cukup layak/tidak layak untuk digunakan.

Uji coba produk dimaksudkan untuk mengumpulkan data yang 
digunakan sebagai pertimbangan dan menetapkan kelayakan handout bioteknologi berbasis kontekstual pada materi bioteknologi. Uji coba produk dilakukan dengan mencobakan handout ke kelompok terbatas. Sampel yang diambil 15 siswa dari jumlah populasi 30 siswa. Penelitian ini dilakukan dengan teknik sampel acak (Random Sampling) pada uji coba produk ini. Siswa diminta untuk mengerjakan handout dengan mencatat pada lembar kerja kesulitan siswa dalam menggunakan handout bioteknologi berbasis kontekstual. Adapun aspek dalam lembar kerja kesulitan siswa selama menyelesaikan handout meliputi kegiatan belajar 1, 2, dan 3. Siswa menjawab soal evaluasi pada handout untuk diketahui hasil penguasaan handout sesuai dengan ketentuan penilaian dan mengisi angket respon terhadap penggunaan handout bioteknolgi berbasis kontekstual yang telah dikembangkan pada akhir uji coba. Uji coba produk handout yang telah selesai dikerjakan segera diketahui hasil belajar siswa dengan cepat dan dapat diketahui hasil penguasaan handout yang telah disusun.

Kegiatan pengambilan data dikelompokkan menjadi dua macam, yaitu data kualitatif dan data kuantitatif yang diijabarkan sebagai berikut: Data kualitatif yaitu tanggapan yang diberikan oleh validator yang berupa kritik atau saran tentang produk handout yang dikembangkan dan kegiatan uji coba kepada siswa kelas XII di SMK Negeri 02 Batu. Data kuantitatif diperoleh hasil pengisian angket oleh ahli handout, ahli materi, dan siswa serta skor hasil uji kompetensi pada saat akhir pembelajaran.

Instrumen yang digunakan untuk pengembangan handout adalah Angket validasi, angket respon siswa, dan keterlaksanaan produk handout.

Data yang diperoleh diolah dengan teknik deskriptif presentase, yaitu mengubah data kuantitatif menjadi bentuk presentase dan kemudian diinterpretasikan dengan kalimat yang bersifat kualitatif. Data kualitatif diperoleh dari kritik dan saran yang diberikan oleh validator ahli handout dan materi, sedangkan data kuantitatif diperoleh dari hasil pengisian angket oleh validator yang berupa skor penilaian. Data yang diperoleh diolah dengan teknik deskriptif presentase, yaitu mengubah data kuantitatif menjadi bentuk presentase dan kemudian diinterpretasikan dengan kalimat yang bersifat kualitatif. Data kualitatif diperoleh dari kritik dan saran yang diberikan oleh validator ahli handout dan materi, sedangkan data kuantitatif diperoleh dari hasil pengisian angket oleh validator yang berupa skor penilaian.

Tabel 1. Kriteria Respon dari Siswa

\begin{tabular}{cc}
\hline Persentase & Keterangan \\
\hline $85 \% \leq \mathrm{RS}$ & Sangat positif \\
$70 \% \leq \mathrm{RS}<85 \%$ & Positif \\
$50 \% \leq \mathrm{RS}<70 \%$ & Kurang positif \\
$\mathrm{RS}<50 \%$ & Tidak positif \\
\hline
\end{tabular}

Data yang diperoleh dari respon siswa yaitu melalui angket yang dikembangkan peneliti digunakan untuk menguji kelayakan tentang bahan ajar berupa handout (Tabel 1).
Uji coba handoutdilaksanakan selama tiga kali pertemuan. Setiap kegiatan belajar dilakukan satu kali pertemuan dengan alokasi waktu $2 \times 45$ menit.

Hasil nilai respon belajar siswa 
tersebut dapat dihitung menggunakan rumus:

$$
\rho=\frac{n}{N} \times 100 \%
$$

(Dimodifikasi Dari Utomo, 2009)

Keterangan:

$\rho=$ Persentase hasil nilai respon siswa

$n=$ Jumlah siswa yang tuntas

$N=$ Jumlah seluruh siswa

\section{HASIL DAN PEMBAHASAN}

Penilaian ahli handout 1 yang mencapai nilai tertinggi yaitu pada aspek halaman sampul (cover) dengan nilai persentase $100 \%$. Aspek halaman sampul (cover) dalam handout tersebut menunjukkan kriteria valid dan ilustrasi gambar yang terdapat dalam handout sudah sangat baik. Penilaian dari ahli handout 1 dengan nilai yang terendah adalah pada aspek rangkuman dan uraian singkat pada materi dengan presentase $60 \%$, dan kegiatan kontekstual dengan persentase $66,67 \%$, sedangkan aspek kegunaan handout dan rujukan dengan presentase hasil $70 \%$, sedangkan petunjuk teknis untuk siswa dan uji kompetensi dengan presentasi hasil $73,33 \%$,isi handout mencapai presentase $75 \%$, tetapi pada aspek tujuan pembelajaran dan gambar mencapai presentase $80 \%$ yang menunjukkan kriteria valid. Rata-rata penilaian validasi oleh ahli handout 1 mencapai 73,48\%, maka dengan persentase $73,48 \%$ handout berbasis kontekstual menunjukkan kriteria "cukup valid" atau cukup layak untuk digunakan.

Tabel 2. Hasil Penilaian Ahli Materi Terhadap Produk Awal Media

\begin{tabular}{ccccc}
\hline No. & Aspek yang Dinilai & Persentase (\%) & Kualifikasi & Keterangan \\
\hline 1. & Tujuan & 75 & Layak & Vaild, Tidak \\
2. & Kebenisi \\
2. & 94 & Sangat Layak & $\begin{array}{c}\text { Sangat Valid, } \\
\text { Tidak Revisi }\end{array}$ \\
3. & $\begin{array}{c}\text { Bahan penarik } \\
\text { perhatian }\end{array}$ & 78 & Sangat Layak & $\begin{array}{c}\text { Sangat Valid, } \\
\text { Tidak Revisi }\end{array}$ \\
4. & Organisasi materi & 75 & Layak & Vaild, Tidak \\
5. & Sumber belasjar & 68 & Layak & Raild, Tidak \\
6. & Evaluasi & 70 & Layak & Raild, Tidak \\
& & & & Revisi \\
\hline
\end{tabular}

Tabel 3. Komentar dan Saran Perbaikan Ahli Materi

\begin{tabular}{|c|c|c|}
\hline No. & Aspek yang Dinilai & Komentar dan Saran Ahli Materi \\
\hline 1. & Tujuan & - \\
\hline 2. & Materi & $\begin{array}{l}\text { Harus ada petunjuk melakukan praktikum tentang } \\
\text { golongan vertebrata dan invertebrata beserata suara, } \\
\text { menambahkan perkembangbiakan beberapa spesies } \\
\text { dari filum nematelminthes. }\end{array}$ \\
\hline 3. & Bahan penarik perhatian & $\begin{array}{c}\text { Tidak ada bahasa lisan. Bahasa lisan pada petunjuk } \\
\text { praktikum dijelaskan secara detail }\end{array}$ \\
\hline 4. & Organisasi Materi & - \\
\hline 5. & Sumber belajar & $\begin{array}{l}\text { Untuk panduan praktikum disertakan bagi setiap } \\
\text { phylum secara singkat dan detail }\end{array}$ \\
\hline 6. & Evaluasi & $\begin{array}{l}\text { Untuk petunjuk pretest/pascatest dan petunjuk } \\
\text { praktikum dijelaskan secara singkat dan jelas. }\end{array}$ \\
\hline
\end{tabular}


Tabel 4. Data Hasil Penilaian Ahli Materi sesudah Revisi

\begin{tabular}{ccccc}
\hline No. & Aspek yang Dinilai & Persentase (\%) & Kualifikasi & Keterangan \\
\hline 1. & Tujuan & 100 & Sangat Layak & Sangat Valid, Tidak Revisi \\
2. & Kebenaran konsep & 97 & Sangat Layak & Sangat Valid, Tidak Revisi \\
3. & Bahan penarik & 93 & Sangat Layak & Sangat Valid, Tidak Revisi \\
& perhatian & & & \\
4. & Organisasi materi & 100 & Sangat Layak & Sangat Valid, Tidak Revisi \\
5. & Sumber belajar & 94 & Sangat Layak & Sangat Valid, Tidak Revisi \\
6. & Evaluasi & 75 & Layak & Vaild, Tidak Revisi \\
\hline
\end{tabular}

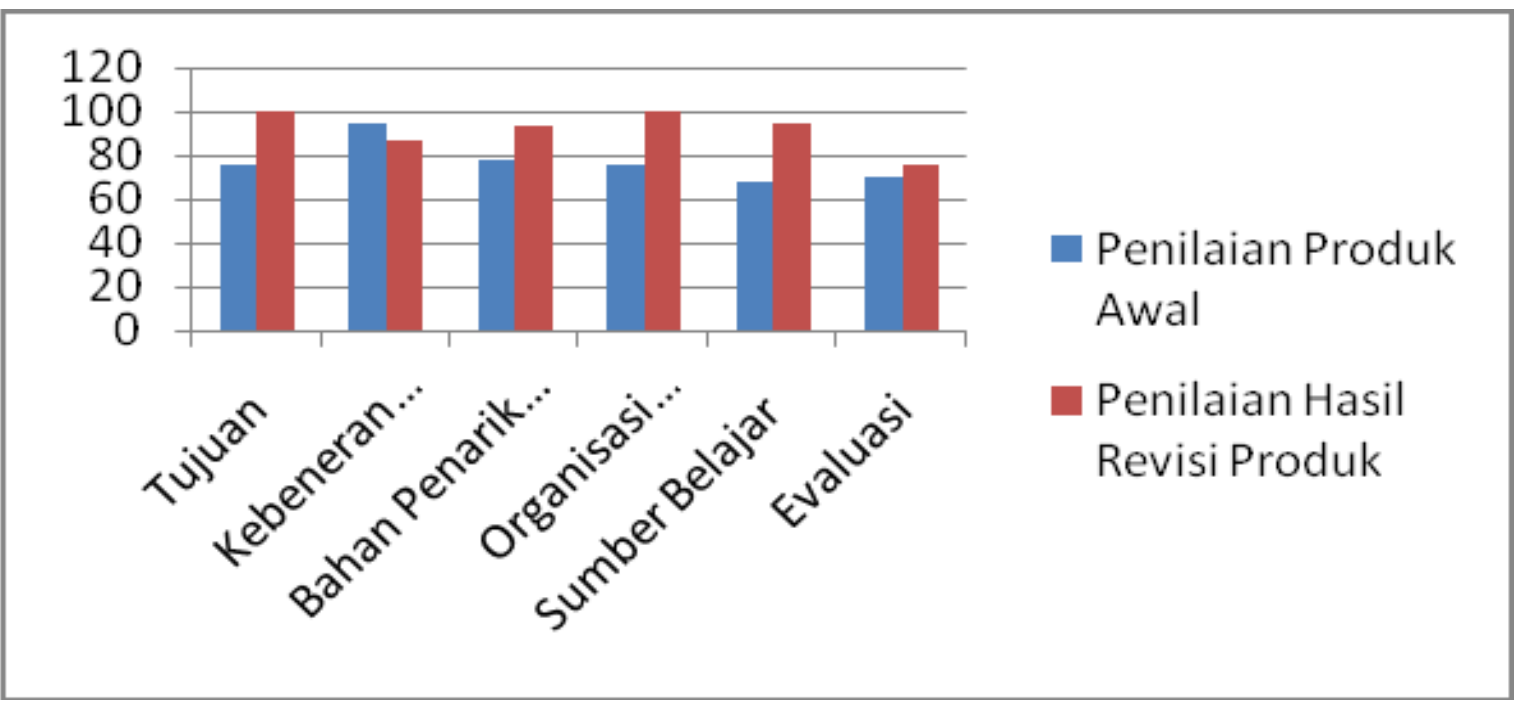

Gambar 2. Grafik perbandingan hasil penilaian produk awal dan revisi produk oleh ahli materi

Tabel 5. Data Hasil Penilaian Ahli Media Sebelum Revisi

\begin{tabular}{|c|c|c|c|c|}
\hline No. & Aspek yang Dinilai & Persentase (\%) & Kualifikasi & Keterangan \\
\hline 1. & Efektifitas & 79 & Sangat Layak & $\begin{array}{l}\text { Sangat Valid, } \\
\text { Tidak Revisi }\end{array}$ \\
\hline 2. & Animasi & 69 & Layak & $\begin{array}{l}\text { Valid, Tidak } \\
\text { Revisi }\end{array}$ \\
\hline 3. & Teks & 83 & Sangat Layak & $\begin{array}{l}\text { Sangat Valid, } \\
\text { Tidak Revisi }\end{array}$ \\
\hline 4. & Audio & 75 & Layak & $\begin{array}{l}\text { Valid, Tidak } \\
\text { Revisi }\end{array}$ \\
\hline 5. & Fasilitas & 88 & Sangat Layak & $\begin{array}{l}\text { Sangat Valid, } \\
\text { Tidak Revisi }\end{array}$ \\
\hline 6. & $\begin{array}{l}\text { Integrasi seluruh aspek } \\
\text { dalam media }\end{array}$ & 50 & Kurang Layak & $\begin{array}{c}\text { Kurang Valid, } \\
\text { Revisi }\end{array}$ \\
\hline 7. & $\begin{array}{c}\text { Penilaian media secara } \\
\text { keseluruhan }\end{array}$ & 75 & Layak & $\begin{array}{c}\text { Valid, Tidak } \\
\text { Revisi } \\
\end{array}$ \\
\hline
\end{tabular}


Tabel 6. Komentar dan Saran Perbaikan Ahli Media

\begin{tabular}{|c|c|c|}
\hline No. & Aspek yang Dinilai & Komentar dan Saran Ahli Media \\
\hline 1. & Efektifitas & $\begin{array}{c}\text { Lengkapi dengan video dan animasi yang menggambarkan } \\
\text { konsep-konsep penting dan buat sajian dalam bentuk sequencing } \\
\text { (satu persatu) }\end{array}$ \\
\hline 2. & Animasi & $\begin{array}{l}\text { Banyak gambar yang terlalu kecil sehingga sulit untuk dibaca. } \\
\text { Sajikan gambar dalam bentuk sequencing atau tahap demi tahap. } \\
\text { Baca lampiran hasil review saya }\end{array}$ \\
\hline 3. & Teks & - \\
\hline 4. & Audio & - \\
\hline 5. & Fasilitas & - \\
\hline 6. & $\begin{array}{l}\text { Integrasi seluruh aspek dalam } \\
\text { media }\end{array}$ & $\begin{array}{l}\text { Sebaiknya animasi yang ditampilkan adalah animasi untuk } \\
\text { menggambarkan konsep materi, bukan asesoris media (missal } \\
\text { intro dll) }\end{array}$ \\
\hline 7. & $\begin{array}{l}\text { Penilaian media secara } \\
\text { keseluruhan }\end{array}$ & Lebih memahami hasil revie ahli media untuk saran perbaikan \\
\hline
\end{tabular}

Tabel 7. Data Hasil Penilaian Ahli Media sesudah Revisi

\begin{tabular}{clccl}
\hline No. & \multicolumn{1}{c}{ Aspek yang Dinilai } & Persentase (\%) & Kualifikasi & \multicolumn{1}{c}{ Keterangan } \\
\hline 1. & Efektifitas & 96 & Sangat Layak & $\begin{array}{l}\text { Sangat Valid, Tidak } \\
\text { Revisi }\end{array}$ \\
2. & Animasi & 100 & Sangat Layak & $\begin{array}{l}\text { Sangat Valid, Tidak } \\
\text { Revisi } \\
\text { Sangat Valid, Tidak }\end{array}$ \\
3. & Teks & 92 & Sangat Layak & $\begin{array}{l}\text { Revisi } \\
\text { Sangat Valid, Tidak } \\
\text { Revisi }\end{array}$ \\
4. Audio & 100 & Sangat Layak & Sangat Valid, Tidak \\
5. & Fasilitas & 100 & Sangat Layak & $\begin{array}{l}\text { Revisi } \\
\text { Sangat Valid, Revisi }\end{array}$ \\
6. & $\begin{array}{l}\text { Integrasi seluruh aspek } \\
\text { dalam media }\end{array}$ & 100 & Sangat Layak & Sangat, Tidak \\
7. Penilaian media secara & 100 & Sangat Layak & $\begin{array}{l}\text { Revisi } \\
\text { keseluruhan }\end{array}$
\end{tabular}

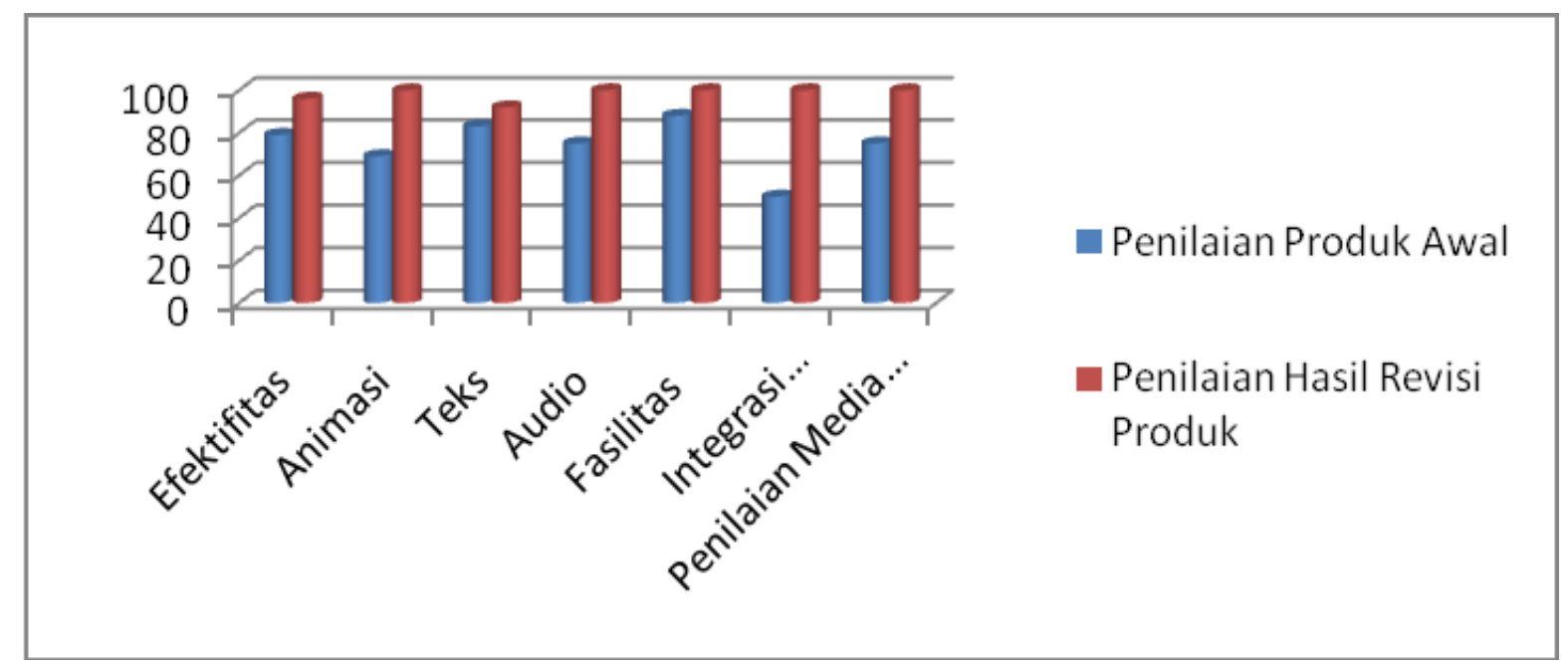

Gambar 3. Grafik perbandingan hasil penilaian produk awal dan revisi produk oleh ahli media 


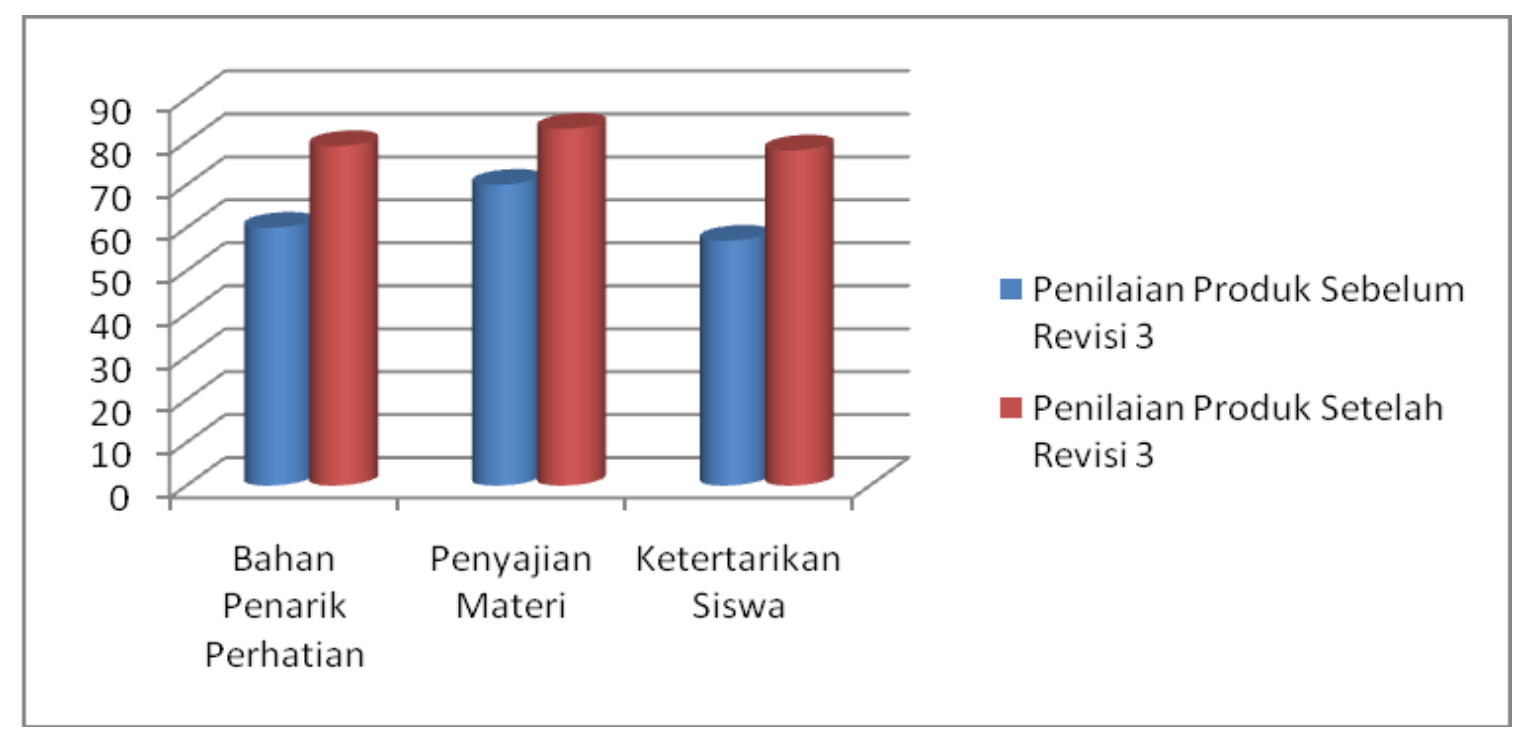

Gambar 4. Grafik perbandingan hasil penilaian produk multimedia interaktif oleh siswa pada uji coba lebih luas

Penilaian siswa terhadap multimedia interaktif pada uji coba lebih luas berturut-turut sebagai berikut: pada aspek penilaian bahan penarik perhatian $79 \%$ dengan kualifikasi sangat layak, aspek penilaian penyajian materi $83 \%$ dengan kualifikasi sangat layak, dan aspek penilaian ketertarikan siswa $78 \%$ dengan kualifikasi sangat layak. Berdasarkan hasil penilaian siswa pada beberapa aspek penilaian maka dapat disimpulkan bahwa media pembelajaran biologi berbasis multimedia interaktif ini sangat layak digunakan dalam pembelajaran.

Untuk menguji keefektifannya multimedia interaktif meningkatkan hasil belajar secara nyata, maka dilakukan uji eksperimen. Uji eksperimen ini menggunakan dua kelas, yaitu kelas kontrol dan keas perlakuan. Pada kelas kontrol siswa hanya diminta membaca buku teks pelajaran setelah diberi pretest. Setelah membaca buku teks pelajaran siswa diberikan postest dengan soal yang sama. Subjek untuk kelas kontrol yaitu kelas X-8 sebanyak 30 orang. Sedangkan untuk kelas perlakukan, awalnya siswa diberikan pretest kemudian di diberikan materi menggunakan multimedia pembelajaran interaktif yang dikembangkan. Setelah diberikan materi lewat penayangan multimedia pembelajaran siswa diberikan pretest. Berdasarkan hasil analisis paired sampel $t$ test dengan menggunakan transform SPSS IBM 21 diperoleh hasil probabilitas (P) pada kelas perlakuan 0,000. Karena nilai $\mathrm{P}<0,05$ maka $\mathrm{H} 0$ ditolak. Rata-rata nilai sebelum menggunakan media pembelajaran berbasis multimedia interaktif \& sesudah menggunakan media pembelajaran berbasis multimedia interaktif adalah berbeda. Perolehan nilai pretest dan postest menunjukkan bahwa terjadi peningkatan skor siswa dan diperoleh rata-rata nilai sebelum menggunakan media (pretest) 41,60 mengalami peningkatan setelah menggunakan media (postest) 90,3. Dengan demikian dapat dinyatakan bahwa: (1) penggunaan media pembelajaran berbasis multimedia interaktif dapat meningkatakan pemaham siswa kelas X-6 pada materi kingdom animalia, (2) media pembelajaran yang dikembangkan sudah memenuhi SK/KD yang telah ditetapkan, karena siswa dapat menjawab soal pretest dan soal postest, (3) media pembelajaran yang 
dikembangkan dapat dijadikan media alternatif pada proses pembelajaran disekolah pada materi kingdom animalia karena media pembelajaran ini sudah dinyatakan sangat valid dan sangat layak digunakan sebagai media pembelajaran oleh ahli media.

Pada kelas kontrol diperoleh nilai probabilitas (P) 0,000. Karena nilai $\mathrm{P}<$ 0,05 maka H0 ditolak, rata-rata nilai pretest dan postest pada kelas kontrol juga berbeda. Berdasarkan perolehan nilai pretest dan postest terjadi peningkatan antara nilai pretest dan postest pada kelas kontrol. Namun perbedaan nilai pretest dan postest pada kelas kontrol tidak terlalu jauh dibandingkan dengan kelas perlakuan. Perolehan rata-rata nilai sebelum membaca buku teks pelajaran (pretest) 48,80 dan rata-rata nilai setelah membaca buku teks pelajaran 68,60. Dengan demikian dapat dinyatakan bahwa penggunaan media pembelajaran berbasis multimedia interaktif dapat meningkatkan pemahaman siswa dan lebih efektif dalam materi kingdom animalia daripada membaca buku teks pelajaran.

\section{KESIMPULAN DAN SARAN}

\section{Kesimpulan}

1. Media pembelajaran yang dikembangkan sangat layak digunakan dalam proses pembelajaran, hal ini berdasarkan pada hasil penilaian ahli media terhadap aspek efektifitas, animasi, teks, audio, dan fasilitas pendukung yang ada pada multimedia interaktif dan ahli materi terhadap aspek tujuan, kebenaran konsep, bahan penarik perhatian, organisasi materi, sumber belajar, dan evaluasi.

2. Media pembelajaran yang dikembangkan sangat efektif digunakan dalam pembelajaran, hal ini berdasarkan pada hasil penilaian ahli media terhadap aspek efektivitas dan siswa terhadap aspek bahan penarik perhatian, penyajian materi dan ketertarikan siswa yang terdapat pada angket siswa pada saat uji coba lebih luas.

3. Media pembelajaran yang dikembangkan dapat meningkatkan pemahaman siswa pada materi Kingdom Animalia, hal ini berdasarkan pada uji coba eksperimen. Pada kelas perlakuan skor pemahaman siswa sebelum menggunaka multimedia interaktif dengan rata-rata 41,60 meningkat menjadi 90,3 setelah menggunakan multimedia interaktif. Sedangkan pada kelas kontrol skor pemahaman siswa sebelum membaca buku teks pelajaran dengan rata-rata 48,80 menjadi 68,60 setelah membaca buku teks pelajaran. Dari hasil uji eksperimen dapat dikatakan bahwa penggunaan media pembelajaran berbasis multimedia interaktif lebih efektif meningkatkan pemahaman siswa dibandingkan dengan menggunakan buku teks pelajaran.

\section{Saran}

1. Multimedia interaktif yang dikembangkan hanya sampai pada tahap uji eksperimen. Diharapkan pengembang berikutnya lebih bisa mengembangkan multimedia interaktif ini pada tahap diseminasi dan implementasi.

2. Multimedia interaktif yang dikembangkan hanya terbatas pada materi Kingdom Animalia, diharapkan semua guru biologi memakai multimedia interaktif sebagai media pembelajaran pada materi lain, karena media ini dapat membuat proses pembelajaran lebih efektif. Terlebih lagi pada semua mata pelajaran. 


\section{DAFTAR PUSTAKA}

Anwar, Khairil. 2007. Pembelajaran Bidang Studi Pendidikan Agama Islam Berbasis Multimedia Di SMP 18. Skripsi, Jurusan Tarbiyah Fakultas Agama Islam Univeritas Muhammadiyah Malang.

Damri, Ari. 2007. Mari Belajar Biologi Untuk SMA-MA Kelas X. Surabaya: SIC

Depdiknas. 2007. Materi Soialisasi Kurikulum dan Pelatihan Tingkat Satuan Pendidikan. Jakarta: Direktorat Jenderal Pendidikan Dasar dan Menengah

Munadi, Yudhi. 2008. Media Pembelajaran Sebuah Pendekatan Baru. Jakarta: Gaung Persada Press

Suciadi, Andreas Andi. 2004. Menggoasai Pembuatan Animasi dengan Macromedia Flash. Jakarta: Elex Media Komputindo.

Sudjadi, Bagod dkk. 2007. Biologi 1 SMA/MA Kelas X. Jakarta: Yudhistira

Sugiyono. 2011. Metode Penelitian Kualitatif Kuantitatif dan $R \& D$. Bandung: Alfabeta Bandung.
Sukmadinata, N. S. 2010. Metode Penelitian Pendidikan. Jakarta: PT Remaja Rosdakarya

Sutopo, Ariesto Hadi. 2002. Animasi dengan Macro Media Flash Berikut Action Script. Jakarta: Salemba Infotek

Warsita, Bambang. 2008. Teknologi Pembelajaran Landasan \& Aplikasinya. Jakarta: Rineka Cipta.

Wulandar,D dan Trianisa K dan R Fendi A. 2006. Flash Card Kalisifikasi Dengan Sistem Pemanfaatan Bridge Untuk Meningkatkan Hasil Belajar Sistem Klasifikasi Makhluk Hidup Pada Siswa SMA. PKMP, Biologi FMIPA Universitas Negeri Malang.

Yamin, Martinis. 2007. Kiat Membelajarkan Siswa. Jakarta: Gaung Persada Press.

Zalikha, Nove. 2008. Pengaruh Penggunaan Multimedia Interaktif Dalam Model Pembelajaran Aktif (Active Learning) Tipe True or False Terhadap Hasil Belajar Biologi Siswa. Skripsi, Fakultas Keguruan dan Ilmu Pendidikan Universitas Sebelas Maret Surakarta. 